Journal of Sustainable Development of Transport and Logistics

journal home page: https://jsdtl.sciview.net

Alghaffari, S., Nguyen, H.-O., \& Chen, P. S.-L. (2018). Critical factors in organisational

effectiveness: The case of Saudi Arabian seaports. Journal of Sustainable Development of

Transport and Logistics, 3(2), 49-65. doi:10.14254/jsdtl.2018.3-2.3.

ISSN 2520-2979

\title{
Critical factors in organisational effectiveness: The case of Saudi Arabian seaports
}

\section{Shadi Alghaffari ${ }^{1,2} \mathbb{D}$, Hong-Oanh Nguyen 1 (D), Peggy Shu-Ling Chen ${ }^{1}$}

${ }^{1}$ Australian Maritime College, The University of Tasmania, 100 Newnham Dr, Newnham TAS 7248, Australia

National Centre for Ports and Shipping

${ }^{2}$ King Abdulaziz University,

Al Ehtifalat St, Jeddah 21589, Saudi Arabia

Faculty of Maritime Studies, Ports and Maritime Transport Department

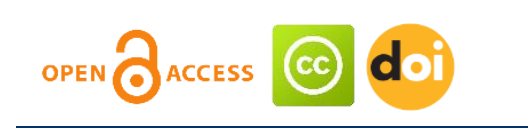

\section{Article history:}

Received: June 29, 2018

1st Revision: August 5, 2018

Accepted: October 19, 2018

\section{DOI:}

10.14254/jsdtl.2018.3-2.3

\begin{abstract}
Seaport management environment has continually changed over the last few decades due to increasing external pressure for seaports to be more competitive, active, dynamic and growing sustainably. These changes have created the need to manage organisational effectiveness in order to monitor port performance and achieve organisational objectives. While organisational effectiveness has been well known in organisational management and important in port management, its application to the seaport sector is limited. This paper presents exploratory research into critical factors of Saudi Arabian seaports' organisational effectiveness. A Delphi method was applied. Data were collected from a two-round survey of the Saudi Arabian seaports, and interviews of 43 senior staff from Saudi Arabian seaports. A mixed method combining quantitative and qualitative analysis was conducted. A total of thirty-one (31) factors from six different dimensions, namely human resource management, customer service, finance, operation, marketing, research \& development, were identified to be influential to $\mathrm{OE}$. The gathered data are no doubt important to seaports because only limited research has been conducted on the application of the organisational effectiveness concept to the seaport sector. Findings of this research regarding selecting and evaluating the most influential factors of $\mathrm{OE}$ are relevant to decision makers in managing seaport organisations.
\end{abstract}

Keywords: Organisational effectiveness, Saudi Arabia, Seaport management, Delphi study, Sustainability.

Corresponding author: Shadi Alghaffari

E-mail: shadi.alghaffari@utas.edu.au 


\section{Introduction}

Organisational effectiveness (OE) can be defined as the effectiveness of an organisation as determined by its ability to achieve its objectives and intended outcomes (Ghorbani \& Sedeh, 2014p. 6). The concept of OE has a long history since the 1950s and provides a basis for management and organisation behaviour theories (Mahoney \& Weitzel, 1969). As a result, many different approaches to OE research have been developed over the years. Notably many factors have been used to evaluate $\mathrm{OE}$, but existing studies use different sets of OE factors. Moreover, the selection of factors may depend on the business nature of the company and, or the sector/industry that is governed by various environmental factors. For example, the seaport sector has gone through rapid changes in recent decades due to its complex environment, and requires effective management to be sustainable. As a result, seaport managers have to take into consideration the long-term evolution of seaport effectiveness.

Previous research identifies various factors to determine the $\mathrm{OE}$ in the seaport sector, but mostly from the perspective of one stakeholder group and some of them may not reflect the dynamic nature of the industry. This study undertakes a refreshing look at the OE concept in the seaport sector. It explores how seaport organisations such as port authorities, terminal operators, and companies manage their $\mathrm{OE}$ to achieve their organisational goals. The Saudi Arabian seaport sector is chosen for this study owing to its critical role in Saudi Arabian exports as the key driver of economic development. It is necessary for the seaports management to improve their competitiveness and efficiency (National Transformation Program, 2016).

The next section reviews the relevant studies on OE, followed by the methodology, a two-round of Delphi study procedure. Subsequently, it presents data analysis and discusses the results. Finally, the paper presents the implications for seaport management and draws the conclusion.

\section{Organisational Effectiveness Dimensions}

Etzioni (1964) defined OE as the degree to which an organisation realises its goals. It is also defined as 'the ability of organisations to acquire and efficiently use available resources to achieve specific goals' (Steers \& Black, 1994, p.326). Thus, the concept of OE goes beyond the efficient use of resources and focuses more on the achievement of organisational goals. Moreover, $\mathrm{OE}$ is specific to organisational goals and therefore it is not possible to evaluate in the same way as efficiency (Charnes, Cooper, \& Rhodes, 1978). Existing studies use various factors to evaluate $\mathrm{OE}$ but there is no common unified set of factors fit all types of organisations. This is because of the diversity of beliefs, cultures across countries and business models, a set of $\mathrm{OE}$ factors that is highly relevant for in a company may not be relevant for another (Ashraf \& Khan, 2013).

Despite of its importance in management, organisational effectiveness is often neglected by organisations in practice (Song \& Panayides, 2015). It would be challenging for an organisation to adapt, compete, cope and survive in the market without monitoring its OE (Sayareh, 2009). OE is critical for seaports due to their capital intensiveness and role in international trade and economic development. Yet, their primary focus in the past was mainly on an operational efficiency measured by Key Performance Indicators (KPIs) (Sayareh, 2007).

The above suggests that $\mathrm{OE}$ factors need to be as comprehensive as possible to consider different environmental factors, business nature, and goals of organisations. Table 1 below presents the $\mathrm{OE}$ factors that have been suggested by existing studies for various industry sectors, such as education, financial institutions, Oil Company and seaports. They are categorised into six dimensions, namely: human resource management (HRM), customers, financial, operations, learning \& growth and market.

The first dimension HRM, which mostly involves the relationship between people working for the organisation and the employer (Saud Mira, Chan Kok, \& Yap Voon, 2017). HRM is the art of managing an organisation's employees and making certain their environment is conducive to working. Employees can work best in an environment that promotes self-growth and positive organisational practices. Employees should be well trained and developed in their various specialities to improve their careers and to increase their productivity. Human resources should be well motivated and provided with incentives, and those who perform well should be rewarded and encouraged. Recognition of high-performing employees is important in ensuring the organisation and the sector are positioned for success. Good communication among the employees and leaders is important, as communication allows diverse thinking and makes it easier to test abilities through training and evaluation.

The second dimension is customers. Many organisations have realised that no business is without satisfied customers who believe in the products or services. For the customers to be fully satisfied, a broad understanding 
of how to meet their needs is required. For example, since seaports serve a wide range of customers, this knowledge will be extremely useful. Any seaport should emphasise the value of a good relationship with customers; however, this is particularly important for seaport and inland companies. Therefore, factors such as customer relationship management and customer responsiveness should be tested.

The third dimension is financial, consisting of two factors such as profitability and financial risk. Business ventures are profit-oriented, and that means they will mostly be involved in satisfying their clients. The reality is that without financial measuring, the business is likely to experience difficult times, and its chances of surviving are significantly reduced (Inoue, 2018).

The fourth dimension is operational. Organisational operational performance is mainly measured by productivity, efficiency, and services quality. However, different business nature may require different factors. For example, safety and security is considered by seaports operations. Productivity and efficiency are the main measures of success in the seaport sector. Evaluating seaport productivity involves measures such as the terminal area equipment utilisation, and storage productivity is one of the productivity factors. Another factor that may influence the OE is service quality, critical to seaport operation success (Cetin \& Cerit, 2010).

Learning and growth is the fifth dimension, relating to the ability to respond to changes in the market and the growth of the sector and other challenges. Growth is associated with various aspects, including equipment, ships, loading, unloading and standard specifications that comply with the global development agenda in managing and controlling seaports. Innovation and the information management factors for seaport management have evolved during the past two decades and should focus on keeping up with competition.

The last dimension is the market, and factors such as market share are vital in developing any business. A business should recognise its main target market as a strategy to increase market share. For instance, the seaport sector could increase market share by seeking to grow customer range, such as shipping lines and the involvement of cargo owners (Sadovaya \& Thai, 2015). There will be less stability and transport quality due to a loss of market share. In this regard, the survivability of the seaport business is pegged on the market share, making some of the ports highly attractive to the private sector. Domestic and international investors are being attracted to the seaport business to improve service delivery. The fast-changing global market requires strategic organisation and relevant effectiveness factors to manage change over time (Bayyurt \& Rizvi, 2015).

\begin{tabular}{|c|c|c|c|}
\hline $\begin{array}{l}\mathrm{OE} \\
\text { dimensions }\end{array}$ & Factors & Studies & Sectors \\
\hline \multirow[t]{8}{*}{ 1. HRM } & Job satisfaction & $\begin{array}{l}\text { Friedlander and Pickle (1968), Negandhi and Reimann } \\
\text { (1973), Quinn and Rohrbaugh (1981), Srivastava } \\
\text { (2008), Ashraf \& Khan (2013), Shoraj and Llaci (2015), } \\
\text { Chuang, Liu \& Chen (2015). }\end{array}$ & $\begin{array}{l}\text { Education, four different } \\
\text { sectors, Cellular } \\
\text { companies Industrial } \\
\text { organisations, General } \\
\text { organization }\end{array}$ \\
\hline & $\begin{array}{l}\text { Employee } \\
\text { engagement }\end{array}$ & Kennedy \& Daim (2010), and Kataria et al. (2012). & $\begin{array}{l}\text { HR Department, General } \\
\text { organisation }\end{array}$ \\
\hline & Good & Shoraj and Llaci (2015). & Bank \\
\hline & $\begin{array}{l}\text { Development and } \\
\text { improvement of } \\
\text { human resources }\end{array}$ & $\begin{array}{l}\text { Sayareh (2006), Sayareh (2009), Cetin and Cerit (2010), } \\
\text { Pouryazdan, Soltani\& Lari (2015). }\end{array}$ & $\begin{array}{l}\text { The oil company, } \\
\text { Seaport }\end{array}$ \\
\hline & Turnover & $\begin{array}{l}\text { Campbell (1973), Campbell (1977), Quinn and } \\
\text { Rohrbaugh (1981), Sayareh (2006), Sayareh (2009). }\end{array}$ & Education, Seaport \\
\hline & Motivation & $\begin{array}{l}\text { Quinn and Rohrbaugh (1981), Thibodeaux and Favilla } \\
\text { (1996), Shoraj and Llaci (2015), Bayyurt \& Rizvi } \\
\text { (2015). }\end{array}$ & Bank, Service industry \\
\hline & Flexibility & $\begin{array}{l}\text { Mott (1972), Quinn and Rohrbaugh (1981), Mendoza } \\
\text { (1993), Cameron (2006), Cetin and Cerit (2010), } \\
\text { Ibrahim, Hamatineghad, Ramezanineghad, and Eydi } \\
\text { (2013), Pouryazdan, Soltani\& Lari(2015). }\end{array}$ & $\begin{array}{l}\text { Oil company, Seaport, } \\
\text { General organisation }\end{array}$ \\
\hline & Leadership & Ashraf \& Khan (2013), Barrick and Bradley (2014). & General organisation \\
\hline 2. Customer & $\begin{array}{l}\text { Customer } \\
\text { relationship } \\
\text { management }\end{array}$ & Elmuti, Jia and Gray (2009). & Financial service \\
\hline
\end{tabular}




\begin{tabular}{|c|c|c|c|}
\hline & $\begin{array}{l}\text { Customer } \\
\text { satisfaction }\end{array}$ & $\begin{array}{l}\text { Sayareh (2006), Elmuti, Jia and Gray (2009), Sayareh } \\
\text { (2009), Cetin and Cerit (2010), Brooks, Schellinck, and } \\
\text { Pallis (2011), Song \& Panayides (2012)Zoogah et al. } \\
(2014), \text { Brooks and Schellinck (2015), Song \& Panayides } \\
\text { (2015), Brooks and Schellinck (2015), Schellinck and } \\
\text { Brooks (2016). }\end{array}$ & $\begin{array}{l}\text { Financial service, } \\
\text { Seaport, General } \\
\text { organisation, Service } \\
\text { industry }\end{array}$ \\
\hline & $\begin{array}{l}\text { Customer } \\
\text { responsiveness }\end{array}$ & Elmuti, Jia and Gray (2009). & Financial service \\
\hline \multirow[t]{2}{*}{ 3. Financial } & Profitability & $\begin{array}{l}\text { Friedlander and Pickle (1968), Child (1975), Sayareh } \\
\text { (2006), Sayareh (2009), Cetin and Cerit (2010), Song \& } \\
\text { Panayides (2012), Aldehayyat and Al Khattab (2013), } \\
\text { Edwinah Amah and Ahiauzu (2013), Zoogah et al. } \\
\text { (2014), Song \& Panayides (2015). }\end{array}$ & $\begin{array}{l}\text { Hotel, Bank, General } \\
\text { organisation, Seaport }\end{array}$ \\
\hline & financial risk & Brooks et al. (2011). & Seaport \\
\hline \multirow[t]{5}{*}{ 4. Operational } & Productivity & $\begin{array}{l}\text { Mahoney and Weitzel (1969), Mott (1972), Campbell } \\
\text { (1973), Price (1977), Quinn and Rohrbaugh (1981), } \\
\text { Robbins \& Barnwell (1994), Schermerhorn \& Osborn } \\
\text { (2004), Sayareh (2006), Sayareh (2009), Cetin and } \\
\text { Cerit (2010)Song \& Panayides (2012), Ibrahim et al. } \\
\text { (2013), Edwinah Amah and Ahiauzu (2013), Zoogah et } \\
\text { al. (2014), Pouryazdan, Soltani\& Lari(2015), Song \& } \\
\text { Panayides (2015). }\end{array}$ & $\begin{array}{l}\text { Sport, bank, Oil } \\
\text { company, seaport, } \\
\text { General organisation }\end{array}$ \\
\hline & Efficiency & $\begin{array}{l}\text { Gibson et al. (1973), Webb (1974), Cunningham (1977), } \\
\text { Mendoza (1993), Sayareh (2006), Cetin and Cerit } \\
\text { (2010), Song \& Panayides (2012), Ashraf \& Khan } \\
\text { (2013), Pouryazdan, Soltani\& Lari(2015), Song \& } \\
\text { Panayides (2015). }\end{array}$ & $\begin{array}{l}\text { The oil company, } \\
\text { Seaport, }\end{array}$ \\
\hline & Services Quality & $\begin{array}{l}\text { Sayareh (2006), Sayareh (2009), Elmuti, Jia, and Gray } \\
\text { (2009), Cetin and Cerit (2010), Brooks et al. (2011), } \\
\text { Song \& Panayides (2012), Song \& Panayides (2015). }\end{array}$ & Seaport, Financial \\
\hline & Safety \& security & Brooks et al. (2011) & Seaport \\
\hline & $\begin{array}{l}\text { Marine } \\
\text { Environment } \\
\text { Protection }\end{array}$ & Brooks et al. (2011) & Seaport \\
\hline \multirow[t]{4}{*}{$\begin{array}{l}\text { 5. Learning \& } \\
\text { Growth }\end{array}$} & Innovation & $\begin{array}{l}\text { Cetin and Cerit (2010), Ashraf \& Khan (2013), Martz } \\
\text { (2013), Zoogah et al. (2014). } \\
\text { Schein (1970), Shirazi, Ardabili and Shirazi (2014), } \\
\text { Bratnicka (2015). }\end{array}$ & $\begin{array}{l}\text { General organisation, } \\
\text { Seaport }\end{array}$ \\
\hline & Growth & $\begin{array}{l}\text { Negandhi and Reimann (1973), Child (1975), Sayareh } \\
\text { (2006), Cornuel, Thomas, Lejeune, and Vas (2009), } \\
\text { Sayareh (2009), Cetin and Cerit (2010), Song \& } \\
\text { Panayides (2012), Zoogah, Peng \& Woldu (2014), Song } \\
\text { \& Panayides (2015). }\end{array}$ & $\begin{array}{l}\text { Education, General } \\
\text { organisation, Seaport, } \\
\text { education }\end{array}$ \\
\hline & Adaptability & $\begin{array}{l}\text { Mott (1972), Mendoza (1993), Sayareh (2006), Sayareh } \\
\text { (2009), Cetin and Cerit (2010), E Amah and Baridam } \\
\text { (2012), Song \& Panayides (2015). }\end{array}$ & $\begin{array}{l}\text { Seaport, Financial, } \\
\text { General organisation }\end{array}$ \\
\hline & $\begin{array}{l}\text { Information and } \\
\text { communication } \\
\text { management }\end{array}$ & $\begin{array}{l}\text { Quinn and Rohrbaugh (1981), Sayareh (2006), Sayareh } \\
\text { (2009), Cetin and Cerit (2010), Song \& Panayides } \\
\text { (2012), Martz (2013), Song \& Panayides (2015), } \\
\text { Pouryazdan, Soltani\& Lari (2015). }\end{array}$ & $\begin{array}{l}\text { General organisation, } \\
\text { Seaport, Oil company }\end{array}$ \\
\hline \multirow[t]{2}{*}{ 6. Market } & Market Share & $\begin{array}{l}\text { Elmuti et al. (2009), Ashraf \& Khan (2013), Edwinah } \\
\text { Amah and Ahiauzu (2013). }\end{array}$ & $\begin{array}{l}\text { Bank, Cellular } \\
\text { Companies, Financial } \\
\text { service }\end{array}$ \\
\hline & Investor Attraction & Zoogah, Peng \& Woldu (2014). & General organisation \\
\hline
\end{tabular}

One of the salient features of the OE research is that while the literature has been able to suggest a comprehensive list of OE factors, these factors have come from studies on various sectors and industries. Thus, there is no warranty that they apply to the seaport sector that this study concerns. There are very limited studies directly related to the $\mathrm{OE}$ of the seaport sector. Given the nature of the seaport sector, for example highly international, capital intensiveness, changing governance and reform models across countries, there could be additional $\mathrm{OE}$ factors distinctive to seaports. The main aim of this study is to address this gap in the OE research in two ways, first it validates the OE factors from the literature review in the seaport context and second, it identifies new OE factors relevant to the seaport sector. The Delphi method is applied to allow the study to 
investigate the subject matter in depth and to identify the critical OE factors through an iterative process of interviewing and surveying participants from the Saudi Arabian seaport sector as a case study.

\section{Methodology: Delphi Research Design}

The Delphi method has a number of advantages and suitability for the current study. It has a substantial advantage in attaining the most consistent agreement of a domain of expertise through serious questionnaires interspersed with organised opinion feedback (Ononiwu, 2013). Cetin and Cerit (2010) stated that the method allows researchers to employ multiple factors in evaluating OE. According to Skulmoski, Hartman, and Krahn (2007), the Delphi method allows the researchers to collect and analyse data while exploring and investigating relatively new concepts based on experts' opinions and feedback. It does not require participating experts to meet physically in one place at the same time (Okoli \& Pawlowski, 2004; Remøy, 2010). The following sub-sections explain how participants were recruited by this study and the Delphi process.

\subsection{Participants Recruitment}

Delphi method does not use a random or general sample of the target population, nor is it intended to produce statistically significant and non-probability sampling (Álvarez, Calvo, \& Mora, 2014; Harmsen et al., 2015; Iden \& Langeland, 2010; Keeney, Hasson, \& McKenna, 2011; Sitlington \& Coetzer, 2013). The Delphi study process does not require a specific sample size (Magalhães-Sant'Ana et al., 2016). For instance, Debecq, Van de Ven and Gustafson (1975) argued that 10 to 15 experts should be sufficient, while Ludwig (1997) contended the majority of Delphi studies utilise 15 to 20 respondents. Wang and Yeo (2017) used 50 participants in their study. The participants should be recognised experts in the field (Gordon, 1992), and selected based on their experience, professional knowledge and interest in participation, in order to increase the content validity of the study (Baker, Lovell, \& Harris, 2006).

In this study, participants representing the Saudi Port Authorities, terminal companies and relevant seaport organisations were recruited, with the aim of analysing any differences in the view of OE among seaport organisations in Saudi Arabia. This study used two approaches to recruiting participants. Firstly, it used publicly available sources such as company websites, LinkedIn, and the Yellow Pages. For each organisation, where applicable, multiple participants were selected from various divisions or departments, including the human resources, operational, financial and marketing departments. A total of 65 potential participants were identified. The second approach was through the assistance from the Saudi Ports Authority as the Government body. A total of 41 Saudi port authorities were contacted through this method. In sum, 106 experts were invited to participate in the interview for round one of the Delphi study.

\subsection{Delphi Process}

A Delphi study is a multi-round cooperative process for ranking and highlighting the opinions of selected skilful managers (James, Aitken, \& Bums, 2002). However, there are no exact guidelines for the precise number of rounds required (Keeney, Hasson, \& McKenna, 2006). Debecq, Van de Ven, and Gustafson (1975) recommended that two or three rounds would be satisfactory for most studies; as the number of rounds increases, more effort is required from the Delphi study participants and, as a result, the response rate may decline (Skulmoski et al., 2007). Lirn, Thanopoulou, Beynon, and Beresford (2004) found that two rounds of Delphi surveys involving industry experts are satisfactory. Linstone and Turoff (2011) highlighted that the number of rounds in the Delphi process depends on when the stability of the responses is attained. This study utilised two rounds in the Delphi process, as the two rounds will be closely synchronised to ensure that a consensus is attained on most of the factors.

After receiving the ethics approval from the Tasmanian Social Sciences Human Research Ethics Committee (HREC), 106 experts were invited to participate in the study via email and telephone. An e-mail was sent to these prospective expert participants with an invitation letter, participant consent form and participant information sheet, explaining the purpose of the study and the research questions. Once participants agreed to participate in this study, the returned a signed copy of consent form to the researcher in person or via email.

A questionnaire was developed for participants to answer in the first round. It consists of demographic questions and a set of five-point Likert-type scale type questions, with (1) not important, (2) less important, (3) 
not sure, (4) important, and (5) very important, to validate the $24 \mathrm{OE}$ factors adopted from the literature. In the first round, of the 106 potential participants invited, forty-three (43) agreed to participate, yielding a response rate of $40 \%$. Among them, thirty-eight (38) were conducted through face-to-face at the participants' workplaces, two (2) participants were interviewed via telephone, and three (3) via e-mail. With the participants' consent, the interviews were recorded, and then transcribed into a Microsoft Word file.

The purpose of the second round was to achieve the following two objectives:

- Obtaining a second consensus evaluation on those five-point Likert-type scale ranking of factors that did not reach the mean of $(\bar{X} \geq 4)$, factors did not reach will be removed from the study, and

- Obtaining a consensus on the explore factors suggested by participants in the first round, identify factors not cover in earlier studies, and narrow down the response by summarising all issues mentioned (Elmousalami, Elyamany, \& Ibrahim, 2018).

In the second round, a summary of the first-round survey results was sent to the participants' individual emails. A short report was prepared with an anonymous summary of the participants' opinions from the previous round, and the experts were informed about the consensus range of factors and can compare this to their answers. This allows the participants to relate their responses to the participants' responses, to review a summary of the first round data and to make any necessary revisions (Becuwe et al., 2017). The procedure followed the process suggested by Hsu and Sandford (2007) in that the first round responses created the foundation for the questionnaire in the second round. Participants were asked to review and comment on the issues and factors discussed.

The second round was administered similarly to the first round, but with a slight change. It was conducted mainly through telephone interviews and emails due to the time and budget concern. Two follow-up emails, friendly reminder via phone were sent to those participants who did not complete the survey within the period. Nevertheless, seven participants did not complete the second-round survey (six participants did not respond, and one participant responded after the deadline). A total of 36 responses were received in the second round, and a response rate of $84 \%$ was achieved. Fig. 1 illustrates the two-round Delphi analysis process of this study.

Figure 1: The two-round Delphi analysis process

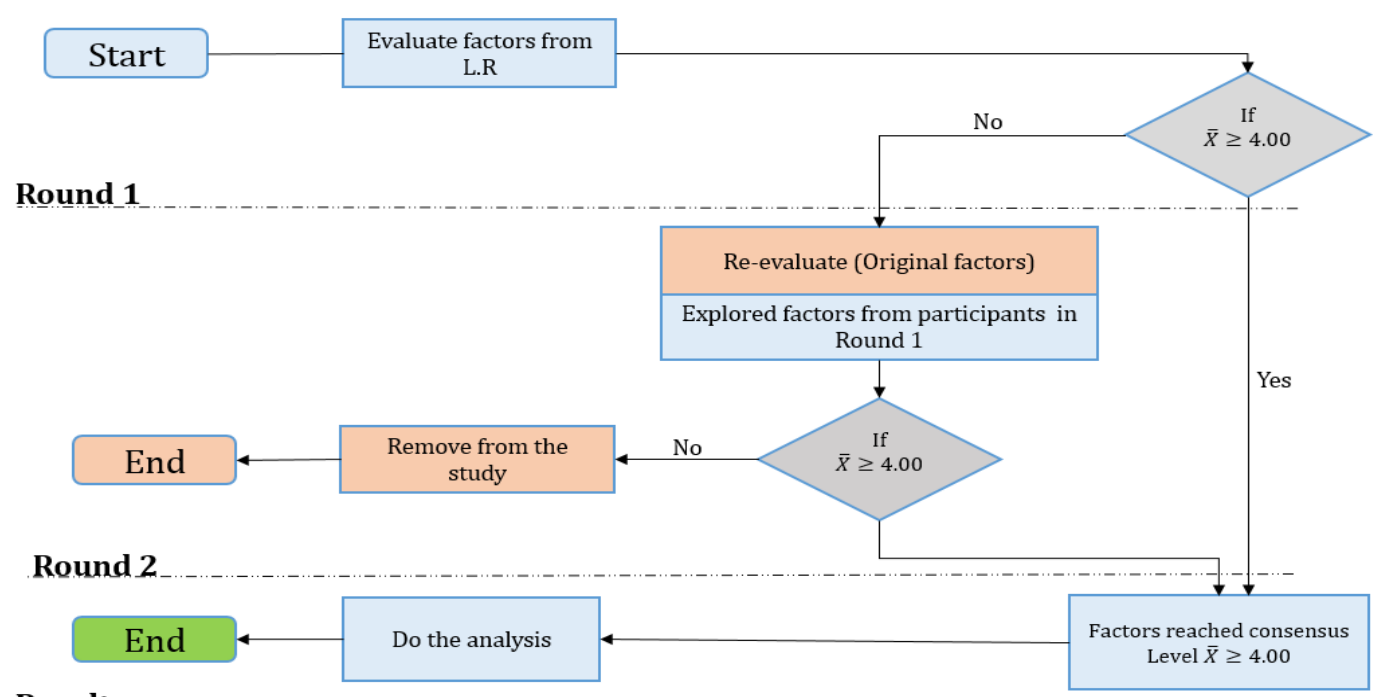

Results

\section{Analysis Results}

\subsection{Demographics of Participants}

As shown in Fig. 2, the participants were from nine seaports. Among them, 37\% came from the Jeddah Islamic Port, the largest seaport in Saudi Arabia and also one of the top nine seaports in the Middle East (Rutter, Chalvatzis, Roper, \& Lettice, 2017). About 9\% from Yanbu Commercial Port and 12\% from the King Fahad Industrial Port, 
both in Yanbu region. Twelve percent (12\%) from Jubail Commercial Port and 9\% the King Fahad Industrial Port of Jubail, the Jubail region. About 14\% from King Abdul-Aziz Port, Dammam region, while $2 \%$ from the Ministry of Transport and 5\% from the national branch of the Ports Authority.

Figure 2: Participants' seaports/organisations

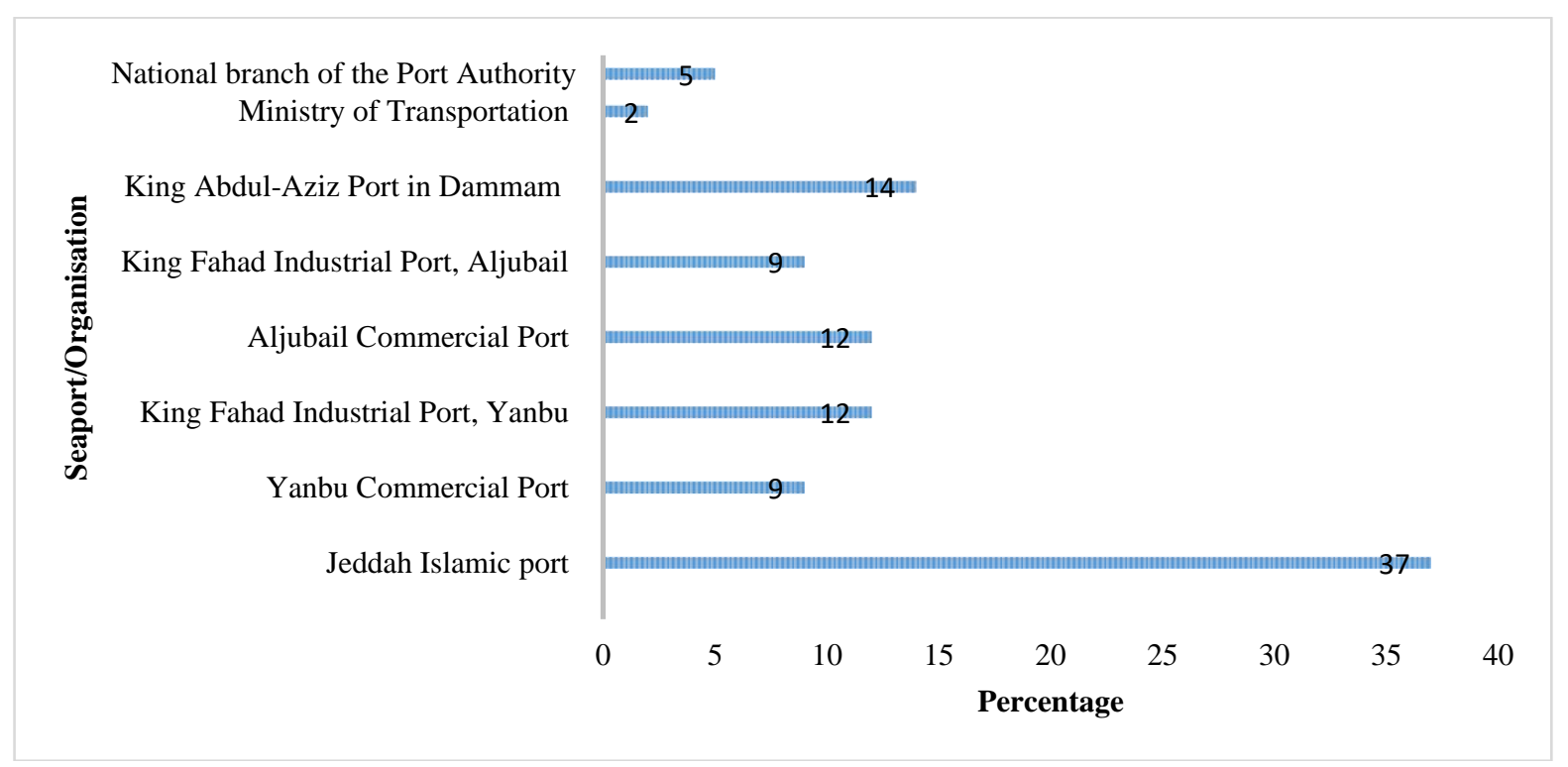

\subsection{First Round Results}

Table 2 shows the first round interview survey results, with descriptive statistics of the $24 \mathrm{OE}$ factors and their respective dimension. OE factors with an average score below the 'consensus' level will be included in the second round of Delphi survey. Shaikh and Khoja (2014) suggested that the consensus level is one of the fundamental elements in Delphi studies, and a sufficiently high consensus level should be utilised as a benchmark for retaining the factors that are preferred by participants in the first round. However, as there is no fixed measure to define the consensus level (Becuwe et al., 2017), variable statistics were used for consideration of the consensus level as suggested by various studies (Richardson, de Leeuw, \& Dullaert, 2016; Gracht, 2012; Harmsen et al., 2015; Tharisara, Kanchana, \& Turner, 2016; Williams, 2016; Hasson, Keeney, \& McKenna, 2000; Hsu and Sandford,2007). Following (Bulger \& Housner, 2007; Green, Jones, Hughes, \& Williams, 1999; Lohuis, van Vuuren, \& Bohlmeijer, 2014; Neuer Colburn, Grothaus, Hays, \& Milliken, 2016), this study uses a consensus level of four for five-point Likert scale questions. Thus, factors with the mean scores $\bar{X} \geq 4$ were retained, while factors with the mean $\bar{X}<$ 4 would be further evaluated in the second round.

The first dimension, the HRM dimension includes eight factors, of which seven met the consensus level $\left(X^{-} \geq 4\right)$. The overall mean of the HR dimension is 4.44 out of 5, implying that this dimension is regarded by participants as crucial to the $\mathrm{OE}$ of seaports. Motivation $(X=4.86, \sigma=0.35)$ was ranked the highest in the level of acceptability and lowest in dispersion between opinions, with the factor deemed either 'very important' or 'important'. Job satisfaction, $\left(X^{-}=4.70, \sigma=0.51\right)$ was ranked second with a marginally higher dispersion in opinions, with a range of two. Other factors such as employee engagement, good communication, development of human resources, flexibility and leadership, were moderately important with their means values between 4.30 and 4.63 . The mean value of employee engagement exceeds four but with a relatively high standard deviation of 0.95 . The employee turnover factor was of the lowest mean $\left(X^{-}=3.53\right)$ and exhibited the highest standard deviation $(\sigma=1.26)$, showing participants' indifference toward it. Thus, employee turnover was included in the second round for further evaluation. The participants added three factors that they considered essential for organisational effectiveness. These include talent management, employee well-being, and employee appreciation, which were added for evaluation in the second round. 


\begin{tabular}{|c|c|c|c|c|c|c|c|}
\hline \multirow[t]{2}{*}{ Dimensions } & \multirow[t]{2}{*}{ Original Factors for R1 (24) } & \multicolumn{6}{|c|}{ Descriptive Statistics } \\
\hline & & Mean & St. Dev & Highest & Lowest & Range & $\begin{array}{l}\text { Dimension } \\
\text { Mean }\end{array}$ \\
\hline \multirow[t]{8}{*}{ HRM } & Job satisfaction & 4.70 & 0.51 & 5 & 3 & 2 & 4.44 \\
\hline & Employee engagement & 4.37 & 0.95 & 5 & 1 & 4 & \\
\hline & Good communication & 4.63 & 0.49 & 5 & 4 & 1 & \\
\hline & Development of human resources & 4.63 & 0.49 & 5 & 4 & 1 & \\
\hline & Employee turnover & 3.53 & 1.26 & 5 & 1 & 4 & \\
\hline & Motivation & 4.86 & 0.35 & 5 & 4 & 1 & \\
\hline & Flexibility & 4.30 & 0.74 & 5 & 2 & 3 & \\
\hline & Leadership & 4.51 & 0.70 & 5 & 2 & 3 & \\
\hline \multirow[t]{3}{*}{ Customer } & Customer relationship management & 4.72 & 0.50 & 5 & 3 & 2 & 4.55 \\
\hline & Customer satisfaction & 4.72 & 0.50 & 5 & 3 & 2 & \\
\hline & Customer responsiveness & 4.21 & 0.99 & 5 & 2 & 3 & \\
\hline \multirow[t]{2}{*}{ Financial } & Profitability & 4.44 & 0.77 & 5 & 2 & 3 & 4.16 \\
\hline & Financial risk & 3.88 & 1.05 & 5 & 1 & 4 & \\
\hline \multirow[t]{5}{*}{ Operational } & Productivity & 4.74 & 0.49 & 5 & 3 & 2 & 4.77 \\
\hline & Efficiency & 4.81 & 0.39 & 5 & 4 & 1 & \\
\hline & Services quality & 4.74 & 0.44 & 5 & 4 & 1 & \\
\hline & Safety \& security & 4.88 & 0.32 & 5 & 4 & 1 & \\
\hline & Marine environment protection & 4.70 & 0.56 & 5 & 3 & 2 & \\
\hline \multirow{4}{*}{$\begin{array}{l}\text { Learning \& } \\
\text { Growth }\end{array}$} & Innovation & 3.65 & 1.27 & 5 & 1 & 4 & 4.19 \\
\hline & Growth & 4.56 & 0.67 & 5 & 2 & 3 & \\
\hline & Adaptability & 4.09 & 0.95 & 5 & 1 & 4 & \\
\hline & $\begin{array}{l}\text { Information } \\
\text { management }\end{array}$ & 4.47 & 0.77 & 5 & 2 & 3 & \\
\hline Market & Market share & 4.53 & 0.67 & 5 & 3 & 2 & 4.62 \\
\hline & Investor attraction & 4.70 & 0.56 & 5 & 3 & 2 & \\
\hline
\end{tabular}

Note. $\mathrm{N}=43$.

The second OE dimension concerns customers. All factors on customer dimension reached the consensus level. Two factors, customer relations management and customer satisfaction, were equally ranked $(\bar{X}=4.72, \sigma=0.50)$, indicating that participants considered both factors equally critical. However, participants' views were more diverse on customer responsiveness $(\bar{X}=4.21, \sigma=0.99)$, which evinced a lower mean opinion and the highest dispersion of opinions from the average participant opinion with a range of two. The overall mean for the customer dimension was 4.51. Participants added two factors, transparency of information and a logistics hub to be evaluated in the next round.

The third dimension, financial dimension included only two factors, namely profitability and financial risk. Participants suggested two new factors, namely financial sustainability and port investment, which were to be included in the second-round survey. Participants ranked profitability $(\bar{X}=4.44, \sigma=0.77)$ as the only factor meeting the threshold, despite some respondents deemed the factor less important. However, the respondents were uncertain about financial risk $(\bar{X}=3.88, \sigma=1.05)$, which failed to meet the consensus level, and with a range of four, implying there were significant differences in opinions on its importance. The mean of the financial dimension was 4.16, the lowest among all six dimensions.

The fourth dimension is operational. All factors in the operational dimension are important. The safety and security factor $(\bar{X}=4.88, \sigma=0.32)$ was ranked as extremely important, with the highest level of agreement and least dispersion of opinion from the average. The other factors in the operational dimension are efficiency $(\bar{X}=4.81$, $\sigma=0.39)$, productivity $(\bar{X}=4.74, \sigma=0.49)$, quality of services $(\bar{X}=4.74, \sigma=0.44)$, and marine environment protection $(\bar{X}=4.70, \sigma=0.56)$. The operational dimension $(\bar{X}=4.77)$ was ranked the highest among the dimensions, suggesting that it is vital to the OE of seaports. Respondents suggested another factor, cooperation between government and port organisations, as essential and thus it was added to the second round for evaluation.

Learning and growth is the fifth dimension. All factors were of mean values $(\bar{X} \geq 4)$ except innovation $(\bar{X}=3.65$, $\sigma=1.27)$. Both the factors growth $(\bar{X}=4.56, \sigma=0.67)$ and information and communication management $(\bar{X}=4.47$, $\sigma=0.77)$ were thought to be of particular importance to OE. Adaptability $(\bar{X}=4.09, \sigma=0.95)$ was thought to be marginally important, with huge differences in opinion on its importance, as depicted by its range of four, but it exhibited a satisfactory level of consensus. The learning and growth dimension had a mean value of 4.19, and was 
deemed essential for the OE of seaports. Participants have also added creative planning and technical excellence as factors for further evaluation in the second round.

The market is the sixth dimension included two factors for evaluation. Participants noted the extreme importance of having investor attraction $(\bar{X}=4.70, \sigma=0.56)$, which ranked marginally above market share $(\bar{X}=4.53$, $\sigma=0.67)$. Both factors are critical, with a range value of two; neither factor was removed, showing that respondents largely agree with their importance to $\mathrm{OE}$. The market dimension had the second-highest mean value overall of 4.62. Participants considered the market for port services a potential additional factor in this dimension, and thus it was further evaluated in the second round.

\subsection{Second Round Results}

In the second round, participants were given a summary of the first-round results. Similar to the first round, they were asked to rate the importance of OE factors. The second round survey included 14 factors, 3 factors that did not meet the consensus level from round one survey and 11 new factors suggested by the participants in the first round. The three factors are employee turnover from the HR dimension, financial risk from the financial dimension and innovation from the learning and growth dimension. As shown in table 3, the results of the secondround show that the mean values of these three factors were still less than 4 after re-evaluation. Therefore, they were excluded from the study.

Table 3: Factors Re-evaluated between rounds

\begin{tabular}{lccccccc}
\hline Factors & R1 Mean & SD & R2 Mean & SD & DF & t test & p value(one tail) \\
\hline Employee turnover & 3.53 & 1.58 & 3.55 & 1.22 & 77 & -0.076 & 0.469 \\
\hline Financial risk & 3.88 & 1.10 & 3.72 & 1.23 & 77 & 0.662 & 0.254 \\
\hline Innovation & 3.65 & 1.61 & 3.75 & 0.99 & 77 & -0.379 & 0.352 \\
\hline
\end{tabular}

In order to investigate whether there was a significant change in participants' opinions between the first round and the second round on the importance of the three factors; a one-tail t-test was performed. Table 4 also shows the results of the hypothesis (one-tail) tests to compare the means of the two rounds. It shows that there is no significant difference in the participants' views between the two rounds, with $p$ values greater than 0.05 . The findings suggest that respondents did not consider employee turnover, financial risk and innovation important contributors to $\mathrm{OE}$ in the seaport.

\section{Table 4: 11 Newly explored factors}

Dimensions $\quad$ Factors for R2

(11)

\begin{tabular}{|c|c|c|c|}
\hline \multirow[t]{4}{*}{ HRM } & Talent & 1. Talent Management, & $8,9,16,22,24,28,32,38$ \\
\hline & Management & 2. Talent acquisition & \\
\hline & $\begin{array}{l}\text { Employee well- } \\
\text { being }\end{array}$ & $\begin{array}{l}\text { 3. Employee well-being, } \\
\text { 4. Friendly teamwork }\end{array}$ & $1,10,19,30,42$ \\
\hline & $\begin{array}{l}\text { Employee } \\
\text { Appreciation }\end{array}$ & $\begin{array}{l}\text { 5. Employee Appreciation, } \\
\text { 6. Employee recognition }\end{array}$ & $15,17,21,38,39,41$ \\
\hline \multirow[t]{2}{*}{ Customer } & $\begin{array}{l}\text { Transparency of } \\
\text { Information }\end{array}$ & $\begin{array}{l}\text { 7. Transparency of Information, } \\
\text { 8. Knowledge of info }\end{array}$ & $1,15,21,24,37,38$ \\
\hline & Logistics hub & $\begin{array}{l}\text { 9. Logistics hub, } \\
\text { 10. Logistics centre }\end{array}$ & $2,16,17,25,39$ \\
\hline \multirow[t]{2}{*}{ Financial } & $\begin{array}{l}\text { Financial } \\
\text { sustainability }\end{array}$ & $\begin{array}{l}\text { 11. Financial sustainability, } \\
\text { 12. Finance stability }\end{array}$ & $4,9,19,25,32,38$ \\
\hline & Port investment & 13. Port investment & $6,14,22,25,39$ \\
\hline Operational & $\begin{array}{l}\text { Cooperation } \\
\text { between } \\
\text { government and } \\
\text { port organisations }\end{array}$ & $\begin{array}{l}\text { 14. Government coop with port bodies, } \\
\text { 15. Port collaboration }\end{array}$ & $5,9,22,30,36$ \\
\hline \multirow{3}{*}{$\begin{array}{l}\text { Learning \& } \\
\text { Growth } \\
\text { Market }\end{array}$} & Creative planning & 16. Creative planning & $5,19,22,34,41$ \\
\hline & $\begin{array}{l}\text { Technical } \\
\text { excellence }\end{array}$ & 17. Technical excellence & $15,22,32,39,43$ \\
\hline & $\begin{array}{l}\text { Port services } \\
\text { market }\end{array}$ & $\begin{array}{l}\text { 18.Port services market, } \\
\text { 19. Expand the port's services internationally }\end{array}$ & $\begin{array}{l}1,5,13,15,21,25,27,28,32,3 \\
3,36,41,42,43\end{array}$ \\
\hline
\end{tabular}


Many researchers have used the Delphi method to obtain experts' views either a suggestion or removal of items (Hsu \& Sandford, 2007; Na, 2006; Shaikh \& Khoja, 2014). In the first round, more than 70\% of the 43 participants provided 19 additional factors, as shown in table 4 . The 19 factors suggested in the first round were analysed, and aspects like meaning and duplication were removed. After duplication was removed, multiple factors were split and similar factors combined. Finally, 11 new factors were added into the second round study and sent to participants via email or telephone.

Table 5 shows the second round results of evaluating the 11 newly explored factors. Ten factors reached the consensus level. Employee well-being was the only factor that did not meet the consensus level and was therefore eliminated from the study. All factors had the standard deviation value equal or over 1 , and a range of 4 . The two factors with the greatest importance in the second round were logistics hub $(\bar{X}=4.85, \sigma=0.60)$ and port investment $(\bar{X}=4.69, \sigma=0.47)$. The logistics hub had the highest mean value $(\bar{X}=4.85)$ while port investment indicated the lowest standard deviation $(\sigma=0.47)$ and the lowest range with a score of 1 . The participants identified four important factors rated between the mean values of 4.31 and 4.64, and a standard deviation between 0.60 and 0.75. These included financial sustainability, creative planning, technical excellence and services. The last four factors were rated between the mean values of 4.03 and 4.31 but with a higher standard deviation range between 0.70 and 0.88. These included transparency of information, cooperation between government and port organisations, talent management and employee appreciation.

\begin{tabular}{|c|c|c|c|c|c|c|}
\hline \multirow[t]{2}{*}{ Dimensions } & \multirow[t]{2}{*}{ Factors for R2 (11) } & \multicolumn{5}{|c|}{ Descriptive Statistics } \\
\hline & & Mean & St. Dev & Highest & Lowest & Range \\
\hline \multirow[t]{3}{*}{ HRM } & Talent Management & 4.25 & 0.87 & 5 & 2 & 3 \\
\hline & Employee well-being & 3.42 & 1.13 & 5 & 1 & 4 \\
\hline & Employee Appreciation & 4.28 & 0.7 & 5 & 3 & 2 \\
\hline \multirow[t]{2}{*}{ Customer } & Transparency of information & 4.03 & 0.84 & 5 & 2 & 3 \\
\hline & Logistics hub & 4.85 & 0.6 & 5 & 3 & 2 \\
\hline \multirow[t]{2}{*}{ Financial } & Financial sustainability & 4.31 & 0.75 & 5 & 2 & 3 \\
\hline & Port investment & 4.69 & 0.47 & 5 & 4 & 1 \\
\hline Operational & $\begin{array}{l}\text { Cooperation between government and } \\
\text { port organisations }\end{array}$ & 4.22 & 0.83 & 5 & 2 & 3 \\
\hline Learning \& & Creative planning & 4.47 & 0.7 & 5 & 2 & 3 \\
\hline Growth & Technical excellence & 4.61 & 0.6 & 5 & 3 & 2 \\
\hline Market & Port services market & 4.64 & 0.68 & 5 & 2 & 3 \\
\hline
\end{tabular}

\section{Note: $\mathrm{N}=36$}

The questionnaire included 24 original factors and 11 factors suggested by participants in the first round. Of these 35 factors, 31 achieved consensus with a mean of four or above for the second round. Tharisara et al. (2016) pointed out that the Delphi process ends when participants reach a minimal consistency in their opinions. This study accepts 31 factors and rejects four factors. This indicates that the study arrived at a reasonable level of consensus on the majority of feedback. Factors are listed in the next section, which provides the results of the second and ranks the factors.

\subsection{Ranking the OE Dimensions and Factors}

The results from the first round ( 21 factors) were combined with those of the second round (10 factors) to generate a final list of 32 factors, organised into six dimensions. These are, operational (6 factors), market ( 3 factors), customer ( 5 factors), HRM (9 factors), financial ( 3 factors) and Learning and Growth ( 5 factors). Table 6 shows the means of each factor and dimension. The two highest-ranked by mean were the operational and market dimensions, with 4.68 and 4.62 respectively. The next two dimensions, customer and HRM, are very close to the mean with 4.51 and 4.50 respectively. The last two dimensions saw a huge jump compared to the first round; both came very near to the mean, indicating a positive change in the agreement. 


\begin{tabular}{|c|c|c|c|c|c|}
\hline Dimension & Rank & Factors & Mean & SD & $\begin{array}{l}\text { Dimension } \\
\text { Mean }\end{array}$ \\
\hline \multirow[t]{6}{*}{ Operational } & 1 & Safety \& security & 4.88 & 0.32 & \multirow[t]{6}{*}{4.68} \\
\hline & 2 & Efficiency & 4.81 & 0.39 & \\
\hline & 3 & Productivity & 4.74 & 0.49 & \\
\hline & 4 & Services quality & 4.74 & 0.44 & \\
\hline & 5 & Marine environment protection & 4.70 & 0.56 & \\
\hline & 6 & Cooperation between government and seaport organisations & 4.22 & 0.83 & \\
\hline \multirow[t]{3}{*}{ Market } & 1 & Investor attraction & 4.70 & 0.56 & \multirow[t]{3}{*}{4.62} \\
\hline & 2 & Port services market & 4.64 & 0.68 & \\
\hline & 3 & Market share & 4.53 & 0.67 & \\
\hline \multirow{5}{*}{ Customer } & 1 & Logistics hub & 4.85 & 0.60 & \multirow{5}{*}{4.51} \\
\hline & 2 & Customer relationship management & 4.72 & 0.50 & \\
\hline & 3 & Customer satisfaction & 4.72 & 0.50 & \\
\hline & 4 & Customer responsiveness & 4.21 & 0.99 & \\
\hline & 5 & Transparency of Information & 4.03 & 0.84 & \\
\hline \multirow[t]{9}{*}{ HRM } & 1 & Motivation & 4.86 & 0.35 & \multirow[t]{9}{*}{4.50} \\
\hline & 2 & Job satisfaction & 4.70 & 0.51 & \\
\hline & 3 & Good communication & 4.63 & 0.49 & \\
\hline & 4 & Development of human resources & 4.63 & 0.49 & \\
\hline & 5 & Leadership & 4.51 & 0.70 & \\
\hline & 6 & Employee engagement & 4.37 & 0.95 & \\
\hline & 7 & Flexibility & 4.30 & 0.74 & \\
\hline & 8 & Employee Appreciation & 4.28 & 0.70 & \\
\hline & 9 & Talent Management & 4.25 & 0.87 & \\
\hline \multirow[t]{3}{*}{ Financial } & 1 & Port investment & 4.69 & 0.47 & \multirow[t]{3}{*}{4.48} \\
\hline & 2 & Profitability & 4.44 & 0.77 & \\
\hline & 3 & Financial sustainability & 4.31 & 0.75 & \\
\hline \multirow{5}{*}{$\begin{array}{l}\text { Learning and } \\
\text { Growth }\end{array}$} & 1 & Technical excellence & 4.61 & 0.60 & \multirow[t]{5}{*}{4.44} \\
\hline & 2 & Growth & 4.56 & 0.67 & \\
\hline & 3 & Information and communication management & 4.47 & 0.77 & \\
\hline & 4 & Creative planning & 4.47 & 0.70 & \\
\hline & 5 & Adaptability & 4.09 & 0.95 & \\
\hline
\end{tabular}

The operational dimension was identified as the most critical dimension with six operational factors. Most of the factors from the first round were rated very important. The only factor added to this group was cooperation between government and seaport organisations, with a mean of 4.22, qualifying as important.

The market demotion included one new factor, the market for port services, with a mean of 4.64. The three factors in this dimension were found to be important, earning the dimension the second-place ranking with a mean of 4.62. The three factors from this dimension.

The customer dimension included five factors. The factor logistics hub was suggested by participants. It was ranked first while the transparency of information ranked last in this dimension and as the least important factor evaluated in this study. Other factors remained the same from the first round. Overall, this dimension was ranked in the third place with a mean of 4.5 .

The HRM dimension, with a mean of 4.50 was ranked in the fourth place, which consists of nine factors. The two factors suggested and found to be important were employee appreciation and talent management. Despite being suggested by participants, both factors rated less important than the original factors, with means between 4.25 and 4.28 .

The financial dimension took fifth place in the ranking. Port investment was the only suggested factor in this category and ranked first, while financial sustainability was deemed less important. Profitability came out in the middle.

The learning and growth dimension was ranked last. The most important factor in this dimension was technical excellence. Technical excellence ranked first with a mean of 4.61. Growth factor was rated at a mean value of 4.56 while, information and communication management and creative planning were both rated 4.47 and tied for fourth place, and the last factor was adaptability, with a mean of 4.09 and less consensus among participants. 


\section{The Implication for Seaport Management}

This study provides a set of OE factors resulted from the Delphi method. It has important references and implications to various seaport organisations in the Saudi Arabian context. The set of OE factors are more practical and applicable because they are identified by a wide range of experts who work in seaport practices. A practical implication for organisations and managers is to make explicit what they are doing and guide actions to drive continuous improvement in the seaport organisations. Findings of this study will allow seaport organisations to take the factors identified into account when evaluating OE of a seaport.

Respondents perceive operational dimension as an important dimension in the seaport sector in Saudi Arabia. Confirming literature findings on the importance of productivity and efficiency resulted in improved operation efficiency (Wilmsmeier \& Sanchez, 2017). Safety and security are an important due to terrorist tactics that could strongly affect civilian's lives and the economy (Wong, Shou, Zhang, \& Ng, 2017). Conflicts might also emerge within the structures of the port governance framework and management. Factors explored such as cooperation between government and seaport organisations is essential for efficient and effectiveness of seaport operations, cooperate and coordinate to gain comprehensive and sustainable benefits and support economic development in the region, which has improved the operation dynamically.

The marketing approach is a vital implementation in seaport development and a core function of seaport management (Cahoon \& Notteboom, 2008; Parola, Pallis, Risitano, \& Ferretti, 2018). In this sense, it is important that port authorities take a more serious attitude in laying out marketing actives for port development in a bid to improve services provided to the investors and the final user. As port authority managers often, interact with carriers and other players affecting cargo moving, intentions to open the market for services provided and increasing the number of service providers. Attracting investor including shipping lines companies, terminal operators, and freight forwarders to work in the Saudi seaport will boost productivity and effectiveness. Market share is the primary factor for marketing dimension, which contributed to seaport expansion and growth as well as benefits to the Saudi's economy.

Customer dimension is indeed found to be significant. Intentions to the customer satisfaction might not be enough to increase the satisfaction for seaport users. Customer relationship management and activating logistics hub might lead to the presence of better service to customer's need. Logistics hub is a relatively current phenomenon that provides service to customers with the aim to cut costs and increase customer satisfaction (Önden, Acar, \& Eldemir, 2016) and to improve customer responsiveness (Pham, Ma, \& Yeo, 2017). Logistics hub could help Saudi seaports to become a platform in the Middle East serving three countries with a focus on the customer responsiveness the development of a Free Zone concept. The customer element could help Saudi seaport compete with other international ports and practised actions will result in key impacts on the national economy.

With regard to the human resource management dimension, the Saudi seaports should pay attention to motivate their employees by setting up specific requirements training programs, and appreciation reword such as providing finances to encourage the employees. Moreover, the Saudi seaport should look forward to improving communication among different management levels. Internally, managers might show an active apprehension for employees by allowing them to contribute to decision-making 'employee's engagement'. In addition, sharp vision and leadership approach to guide and organiser of the march of the coming years. The approach to managing human resources would lead to successful seaport management. These results echo and confirm similar recent research in Taiwan (Tseng \& Pilcher, 2017). Overall, looking at the HRM dimension, the seaport would result in a positive impact for organisational effectiveness.

It seems that profitability is not the prime objective, taking into account the financial aspects of seaport organisations. However, to keep seaport financially sustainable, increasing investments has great importance. Seaport investment is essential to improved integrate services and enable the clustering of or provide assisting infrastructures. Such investments support port performance, reputation and competitiveness. With findings from previous research that stress port investment contributed significantly to the seaport effectiveness (Wilmsmeier \& Sanchez, 2017).

The ability to maintain learning and growth of seaport is also a critical dimension. Continuous learning and understanding recent technology helps leaders to become more effective. This could be achieved by measuring various factors such as technical excellence and implementing information and communication management to enhance effectiveness in the seaport. Additionally, comments that adapt to the current situation and any technology variables help to understand the way managers learn and grow skills needed for the new era. 


\section{Conclusion}

The current study presents existing OE factors through a literature review to identify the key and most important factors in seaports sector. This paper involved the participation of qualified and knowledgeable members of the seaport sector. The participants were invited from seaport organisations including the Saudi port authority and terminal companies. They shared their experience in identifying and exploring factors of success in seaport management.

The results of the first round began with a list of 24 factors gathered from a literature review, with 21 factors reaching the level of consensus. The identified elements were rated through Delphi method using a five-point Likert scale, face-to-face and telephone interviews techniques. The outcome of the second round validated those of the first round, in addition to the explored factors. Accordingly, 31 factors that reached the consensus level, highlighting their importance to $\mathrm{OE}$ in the seaport sector.

This study provides valuable insights for the development of seaport management by highlighting the importance of understanding the Saudi Arabian seaport's environment and culture. The results of this study could benefit and provide guidelines to Saudi Arabia's seaport leaders and stakeholders based on limited resources. The set of $\mathrm{OE}$ seaport factors are more practical and applicable because they are identified by a wide range of views of participants who worked on Saudi Arabian seaports and were brought together to establish a consensus about factors important to the implementation of $\mathrm{OE}$.

\section{Acknowledgements}

The anonymous Delphi participants are genially thanked for their essential contributions to the study.

\section{Appendix A. Supplementary material}

Supplementary data associated with this article can be found, in the online version, at https://jsdtl.sciview.net

\section{Funding}

The authors received no direct funding for this research.

\section{Citation information}

Alghaffari, S., Nguyen, H.-O., \& Chen, P. S.-L. (2018). Critical factors in organisational effectiveness: The case of Saudi Arabian seaports. Journal of Sustainable Development of Transport and Logistics, 3(2), 6-22. doi:10.14254/jsdtl.2018.3-2.1

\section{References}

Aldehayyat, J., \& Al Khattab, A. (2013). Strategic planning and organisational effectiveness in Jordanian Hotels. International Journal of Business and Management, 8(1), 11. doi: http://dx.doi.org/10.5539/ijbm.v8n1p11

Alghaffari, S., Nguyen, H.-O., Chen, P., \& Enshaei, H. (2016). Organisational effectiveness and its implications for seaports. World Academy of Science, Engineering and Technology. International Journal of Social, Behavioral, Educational, Economic, Business and Industrial Engineering, 10(11), 3459-3463.

Álvarez, I., Calvo, J. A., \& Mora, A. (2014). Involving academics in the accounting standard setting process: An application of the Delphi methodology to the assessment of IASB proposals. Journal of Management \& Governance, 18(3), 765-791. doi: 10.1007/s10997-012-9244-3

Amah, E., \& Ahiauzu, A. (2013). Employee involvement and organizational effectiveness. Journal of Management Development, 32(7), 661-674. doi: 10.1108/jmd-09-2010-0064

Amah, E., \& Baridam, D. (2012). Adaptability and organizational effectiveness: A study of the Nigerian banking industry. International Journal of Business and Management Tomorrow, 2(3), 1-10.

Ashraf, F., \& Khan, M. A. (2013). Organizational innovation and organizational effectiveness among employees of cellular companies. Pakistan Journal of Psychological Research, 28(1), 1-24. 
Baker, J., Lovell, K., \& Harris, N. (2006). How expert are the experts? An exploration of the concept of 'expert' within Delphi panel techniques. Nurse Researcher (through 2013), 14(1), 59.

Becuwe, H. b. g. c., Roblin, N. P., Tondeur, J., Thys, J., Castelein, E., \& Voogt, J. (2017). Conditions for the successful implementation of teacher educator design teams for ICT integration: A Delphi study. Australasian Journal of Educational Technology, 33(2), 159-172.

Bratnicka, K. (2015). Creativity and effectiveness in organizations. A new approach to an old question1. Management, 19(1). doi: 10.1515/manment-2015-0003

Brooks, \& Schellinck. (2015). Measuring port effectiveness: What really determines cargo interests' evaluations of port service delivery? Maritime Policy \& Management, 42(7), 699.

Brooks, Schellinck, T., \& Pallis, A. A. (2011). A systematic approach for evaluating port effectiveness. Maritime Policy \& Management, 38(3), 315-334.

Bulger, S. M., \& Housner, L. D. (2007). Modified Delphi investigation of exercise science in physical education teacher education. Journal of Teaching in Physical Education, 26(1), 57-80.

Cahoon, S., \& Notteboom, T. (2008). Port marketing tools in a logistics-restructured market environment: The quest for port loyalty. Paper presented at the IAME: International Association of Maritime Economists Annual Conference.

Campbell, J. P. (1973). Research into the nature of organizational effectiveness: An endangered species? Unpublished Manuscript, University of Minnesota.

Cetin, C. K., \& Cerit, A. G. (2010). Organizational effectiveness at seaports: A systems approach. Maritime Policy \& Management, 37(3), 195-219. doi: 10.1080/03088831003700611

Charnes, A., Cooper, W. W., \& Rhodes, E. (1978). Measuring the efficiency of decision making units. European Journal of Operational Research, 2, 429-444.

Cornuel, E., Thomas, H., Lejeune, C., \& Vas, A. (2009). Organizational culture and effectiveness in business schools: A test of the accreditation impact. Journal of Management Development, 28(8), 728-741.

Debecq, A., Van de Ven, A. H., \& Gustafson, D. (1975). Group techniques for program planning. Glenview, Illinois: Scott, Foresman and Company.

Elmousalami, H. H., Elyamany, A. H., \& Ibrahim, A. H. (2018). Evaluation of cost drivers for field canals improvement projects. Water Resources Management, 32(1), 53-65. doi: 10.1007/s11269-017-1747-x

Elmuti, D., Jia, H., \& Gray, D. (2009). Customer relationship management strategic application and organizational effectiveness: An empirical investigation. Journal of Strategic marketing, 17(1), 75-96.

Etzioni, A. (1964). Modern organizations. Foundations of modern sociology series: Prentice-Hall, Englewood Cliffs, NJ.

Ghorbani, H., \& Sedeh, H. A. (2014). An empirical investigation on the impact of internal marketing on organizational effectiveness within human resource capabilities perspective (Case study: Islamic Azad University branches in region 4 of Isfahan municipality). International Journal of Academic Research in Business and Social Sciences, 4(1), 635.

Gordon, T. J. (1992). The methods of futures research. The Annals of the American Academy of Political and Social Science, 25-35.

Gracht, H. (2012). Consensus measurement in Delphi studies. Technological Forecasting and Social Change, 79(8), 1525-1536. doi: 10.1016/j.techfore.2012.04.013

Green, B., Jones, M., Hughes, D., \& Williams, A. (1999). Applying the Delphi technique in a study of GPs' information requirements. Health \& Social Care in the Community, 7(3), 198-205. 
Harmsen, A. M., Geeraedts, L. M., Giannakopoulos, G. F., Terra, M., Christiaans, H. M., Mokkink, L. B., \& Bloemers, F. W. (2015). Protocol of the DENIM study: A Delphi-procedure on the identification of trauma patients in need of care by physician-staffed Mobile Medical Teams in the Netherlands. Scand J Trauma Resusc Emerg Med, 23, 15. doi: 10.1186/s13049-015-0089-z

Hasson, F., Keeney, S., \& McKenna, H. (2000). Research guidelines for the Delphi survey technique. Journal of Advanced Nursing, 32(4), 1008-1015.

Hsu, C.-C., \& Sandford, B. A. (2007). The Delphi technique: Making sense of consensus. Practical assessment, research \& evaluation, 12(10), 1-8.

Ibrahim, A., Hamatineghad, M., Ramezanineghad, R., \& Eydi, H. (2013). Designing organizational effectiveness model of selected Iraq's sporting federations based on competing values framework. Choregia, 9(1). doi: $10.4127 /$ ch.2013.0077

Iden, J., \& Langeland, L. (2010). Setting the stage for a successful ITIL adoption: A Delphi study of IT experts in the Norwegian armed forces. Information Systems Management, 27(2), 103-112. doi: $10.1080 / 10580531003708378$

Inoue, S. (2018). Realities and challenges of port alliance in Japan - Ports of Kobe and Osaka. Research in Transportation Business \& Management. 26, 45-55. doi: 10.1016/j.rtbm.2018.02.004

James, P., Aitken, P., \& Bums, T. (2002). Research priorities for primary care mental health: A Delphi. Primary Care Psychiatry, 8(1), 27-30.

Keeney, S., Hasson, F., \& McKenna, H. (2006). Consulting the oracle: Ten lessons from using the Delphi technique in nursing research. Journal of Advanced Nursing, 53(2), 205-212. doi: 10.1111/j.1365-2648.2006.03716.x

Keeney, S., Hasson, F., \& McKenna, H. (2011). The Delphi technique in nursing and health research (pp. 43-68). Chichester, West Sussex, U.K: Wiley-Blackwell.

Kennedy, E., \& Daim, T. U. (2010). A strategy to assist management in workforce engagement and employee retention in the high tech engineering environment. Eval Program Plann, 33(4), 468-476. doi: 10.1016/j.evalprogplan.2009.12.001

Linstone, H. A., \& Turoff, M. (2011). Delphi: A brief look backward and forward. Technological forecasting and social change, 78(9), 1712-1719. doi: http://dx.doi.org/10.1016/j.techfore.2010.09.011

Lirn, T. C., Thanopoulou, H. A., Beynon, M. J., \& Beresford, A. K. C. (2004). An application of AHP on transhipment port selection: A Global perspective. Maritime Economics \& Logistics, 6(1), 70-91. doi: 10.1057/palgrave.mel.9100093

Lohuis, A. M., van Vuuren, M., \& Bohlmeijer, E. (2014). Context-specific definitions of organizational concepts: Defining 'team effectiveness' with use of the Delphi Technique. Journal of Management \& Organization, 19(06), 706-720. doi: 10.1017/jmo.2014.10

Mahoney, T. A., \& Weitzel, a. W. (1969). Managerial models of organizational effectiveness. Sage Publications, Inc, 14(3).

Mendoza, R. (1993). Putting organizational effectiveness into practice the preeminent consultation. Journal of Cunseling \& Development, 72(2), 168-177. doi: 10.1002/j.1556-6676.1993.tb00917.x

Mott, P. E. (1972). The characteristics of effective organizations: Harper Collins Publishers.

Na, S. (2006). A Delphi study to identify teaching competencies of teacher education faculty in 2015: West Virginia University.

Neuer Colburn, A. A., Grothaus, T., Hays, D. G., \& Milliken, T. (2016). A Delphi study and initial validation of counselor supervision competencies. Counselor Education and Supervision, 55(1), 2-15. doi: 10.1002/ceas.12029 
Okoli, C., \& Pawlowski, S. D. (2004). The Delphi method as a research tool: An example, design considerations and applications. Information \& Management, 42(1), 15-29. doi: http://dx.doi.org/10.1016/j.im.2003.11.002

Önden, İ., Acar, A. Z., \& Eldemir, F. (2016). Evaluation of the logistics center locations using a multi-criteria spatial approach. Transport, 33(2), 322-334, 1-13. doi: 10.3846/16484142.2016.1186113

Ononiwu, C. G. (2013). A Delphi examination of inhibitors of the effective use of process industry Enterprise Resource Planning (ERP) systems: A case study of New Zealand's process industry. The Electronic Journal Information Systems Evaluation, 16(2), 114-131.

Parola, F., Pallis, A. A., Risitano, M., \& Ferretti, M. (2018). Marketing strategies of port authorities: A multidimensional theorisation. Transportation Research Part A: Policy and Practice, 111, 199-212. doi: 10.1016/j.tra.2018.03.012

Pham, T. Y., Ma, H. M., \& Yeo, G. T. (2017). Application of Fuzzy Delphi TOPSIS to locate logistics centers in Vietnam: The Logisticians' perspective. The Asian Journal of Shipping and Logistics, 33(4), 211-219. doi: 10.1016/j.ajsl.2017.12.004

National Transformation Program. (2016). National Transformation Program 2020.

Quinn, R. E., \& Rohrbaugh, J. (1981). A competing values approach to organizational effectiveness. Public Productivity Review, 5(2), 122-140. doi: 10.2307/3380029

Remøy, H. T. (2010). Out of office: A study on the cause of office vacancy and transformation as a means to cope and prevent: Amsterdam: IOS Press.

Richardson, D. A., de Leeuw, S., \& Dullaert, W. (2016). Factors affecting global inventory prepositioning locations in humanitarian operations-A Delphi Study. Journal of Business Logistics, 37(1), 59-74. doi: 10.1111/jbl.12112

Rutter, R., Chalvatzis, K. J., Roper, S., \& Lettice, F. (2017). Branding instead of product innovation: a study on the brand personalities of the UK's electricity market. European Management Review.

Sadovaya, E., \& Thai, V. V. (2015). Impacts of implementation of the effective maritime security management model (EMSMM) on organizational performance of shipping companies. The Asian Journal of Shipping and Logistics, 31(2), 195-215. doi: 10.1016/j.ajsl.2015.06.002

Saud Mira, M., Chan Kok, T., \& Yap Voon, C. (2017). The impact of HRM practices and employees' job satisfaction on employees' performance at Saudi Ports Authority. Annual International Conference on Enterprise Marketing \& Globalization, 140-147. doi: 10.5176/2251-2349_HRM\&PD17.38

Sayareh. (2009). A model for organisational effectiveness (oe) assessment in seaport organisations. Paper presented at the IAME Annual Conference.

Sayareh, J. (2007). Benefits of regular organisational effectiveness (OE) assessment in seaport organisations. Proceedings of The International Association of Maritime Economics (IAME). Athens, Greece.

Schellinck, T., \& Brooks, M. R. (2016). Developing an instrument to assess seaport effectiveness in service delivery. International Journal of Logistics Research and Applications, 19(2), 143-157. doi: $10.1080 / 13675567.2015 .1059412$

Shaikh, Z. A., \& Khoja, S. A. (2014). Personal learning environments and university teacher roles explored using Delphi. Australasian Journal of Educational Technology, 30(2), 202-226.

Shoraj, D., \& Llaci, S. (2015). Motivation and its impact on organizational effectiveness in Albanian businesses. SAGE Open, 5(2). doi: 10.1177/2158244015582229

Sitlington, H., \& Coetzer, A. (2013). Using the Delphi Technique to identify components of a tertiary strategic HRM curriculum. eCULTURE, 5(1), 1.

Skulmoski, G. J., Hartman, F. T., \& Krahn, J. (2007). The Delphi method for graduate research. Journal of Information Technology Education, 6, 1. 
Song, D.-W., \& Panayides, P. (2015). Maritime logistics: A guide to contemporary shipping and port management. Retrieved from: http://UTAS.eblib.com.au/patron/FullRecord.aspx?p=2006879

Steers, \& Black. (1994). Organizational Behavior: New York: Harper Collins College Publisher.

Tharisara, S., Kanchana, R., \& Turner, G. D. H. (2016). A policy of informed consent for biobanking in tropical disease research projects, using the Delphi Technique: Principles for good practice. Indian Journal of Public Health Research \& Development, 7(4), 282-288. doi: 10.5958/0976-5506.2016.00235.7

Thibodeaux, M. S., \& Favilla, E. (1996). Organizational effectiveness and commitment through strategic management. Industrial Management \& Data Systems, 96(5), 21-25.

Tseng, P.-H., \& Pilcher, N. (2017). Port governance in Taiwan: How hypocrisy helps meet aspirations of change. Research in Transportation Business \& Management, 22 (Supplement C), 38-48. doi: https://doi.org/10.1016/j.rtbm.2016.07.003

Williams, S. (2016). Chiropractors' perception of occupational stress and its influencing factors: A qualitative study using responses to open-ended questions. Chiropractic \& Manual Therapies, 24,1-7. doi: 10.1186/s12998-0160083-1

Wilmsmeier, G., \& Sanchez, R. J. (2017). Evolution of national port governance and interport competition in Chile. Research in Transportation Business \& Management, 22, 171-183. doi: 10.1016/j.rtbm.2017.01.001

Wong, K. H. T., Shou, E. C., Zhang, H., \& Ng, A. K. Y. (2017). Strategy formulation of new generation ports: A case study of Hong Kong International Terminals Ltd. (HIT). Research in Transportation Business \& Management, 22, 239-254. doi: 10.1016/j.rtbm.2016.09.001

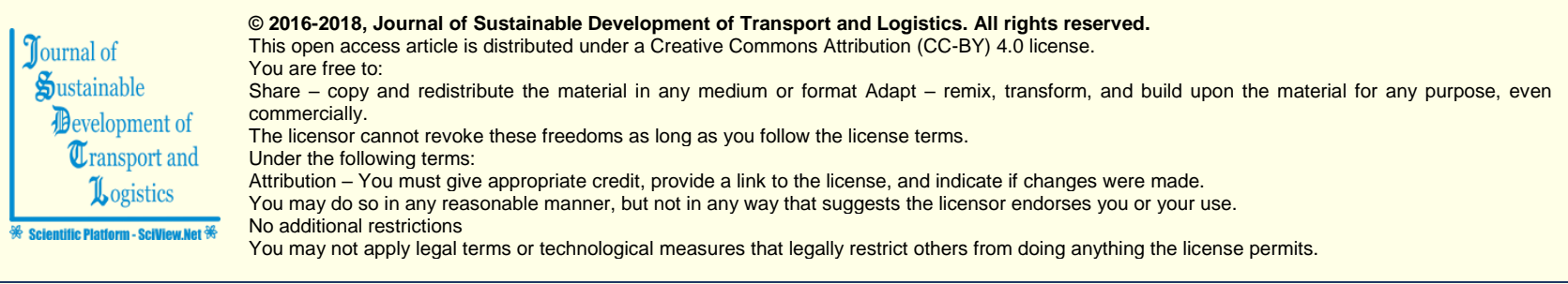

Journal of Sustainable Development of Transport and Logistics (ISSN: 2520-2979) is published by Scientific Publishing House "CSR", Poland, EU and Scientific Publishing House "SciView", Poland, EU

Publishing with JSDTL ensures:

- Immediate, universal access to your article on publication

- High visibility and discoverability via the JSDTL website

- Rapid publication

- Guaranteed legacy preservation of your article

- Discounts and waivers for authors in developing regions

Submit your manuscript to a JSDTL at https://jsdtl.sciview.net/ or submit.jsdtl@sciview.net 